\title{
INFORMASI ARUS DAN SUHU TRAFO 150/20 KV PADA GARDU INDUK SEGOROMADU BERBASIS MIKROKONTROLER DAN SMS
}

\author{
1) Jarot Suhardi, ${ }^{2)}$ Misbah, \\ 1,2,3) Jurusan Teknik Elektro, Fakultas Teknik, Universitas Muhammadiyah Gresik \\ J1. Sumatera No 101, Gresik 61121, Jawa Timur \\ E-mail:jarotsuhardi@gmail.com ${ }^{1)}$, misbah.grs@ gmail.com ${ }^{2)}$
}

\begin{abstract}
ABSTRAK
Pada operasi penyaluran tenaga listrik Perusahaan Listrik Negara (PLN) menjadi elemen vital yang mutlak dibutuhkan. Tranformator dapat dikatakan jantung tranmisi dan distribusi dalam kondisi ini, secara umum perubahan data Arus dan Suhu dapat sewaktu - waktu berubah,

Bila terjadi beban lebih pada Tranformator, petugas gardu induk akan mendapatkan informasi dari alat informasi Arus dan Suhu Tranformator 150/20 KV 60 MVA pada Gardu Induk Segoromadu berupa sms. Pada penelitian ini menggunakan mikrokontroler ATMega16 sebagaj control unit yang akan memproses data yang diterima dari sensor Arus ACS712 dan sensor Suhu LM35 dan ditampilkan pada layar LCD 2x16, dan dikirim melalui sms ke petugas Gardu Induk Segoromadu.

Sensor Arus ACS712 yang dipakai pada alat ini mampu membaca arus listrik 0 sampai 5 Ampere, output dari Sensor Arus ACS712 pada saat tidak ada beban adalah 2,5V dan jika ditambahkan beban akan bertambah $\pm 185 \mathrm{mV} /$ Ampere. Sensor Suhu IC LM35 yang dipakai pad $\varepsilon$ alat ini mampu membaca $-55^{\circ} \mathrm{C}-150^{\circ} \mathrm{C}$, Dari hasil pengujian diketahui tegangan keluaran sensor naik sebesar $10 \mathrm{mV}$ untuk setiap kenaikan $1{ }^{\circ} \mathrm{C}$ atau $10 \mathrm{mV} /{ }^{\circ} \mathrm{C}$ dan apabila terjadi beban lebih pada trafo 150/20 Kv 60Mva pada set poin 3 Ampere Arus CT (Current Transformer) atau suhu $>50^{\circ} \mathrm{C}$ maka memberi informasi berupa Sms, sehingga dapat digunakan sebagai sistem informasi yang lebih cepat memberikan informasi apabila terjadi ganguan beban lebih. Tingkat akurasi dari sensor ACS712 dibandingkan dengan clamp Ampere meter memiliki nilai error maksimum pada sensor yaitu 1,39\% dengan beban yang diukur sebesar 3 Ampere.
\end{abstract}

Kata Kunci : Arus, Suhu, Transformator, Mikrokontroler ATMegal6, Sms.

\section{PENDAHULUAN}

Perusahaan Listrik Negara (PLN) menjadi elemen vital yang mutlak di butuhkan. P3B sebagai salah satu Perusahaan Listrik Negara yang membidangi di bagian penyaluran dan pengatur beban memegang peranan penting tersebut. Gardu Induk Segoromadu contohnya selaku pusat distribusi listrik bertegangan tinggi antara 150/70 KV mensupply beberapa industri besar seperti Pt. Semen indonesia, Pt.Barata indonesia.
Dan 150/20 KV Mensupply Pt. Wilmar, Pt. Gramitrama, Pt. Nusantara. dan sisanya untuk konsumsi masyrakat sekitar sepeti Desa Romokalisari, Desa Panglima Sudirman, dll.

Gardu Induk Segoromadu merupakan Gardu Induk yang tertua diantara Gardu Induk lainnya, dan peralatan yang tersedia mulai dari tahun 1976 sampai sekarang, peralatan tersebut membutuhkan perawatan dan pemantauan yang extra supaya bisa bekerja semaksimal mungkin. Dan di Gardu Induk Segoromadu mempunyai beberapa SDM yang terbatas sehingga tidak bisa memantau kondisi 
tranformator bila terjadi lonjakan beban lebih dan suhu naik. Untuk itu keberadaan petugas sangat penting untuk memantau kondisi Tansformator tersebut. Bila terjadi beban lebih pada Tranformator, petugas bisa mengalihkan ke jaringan Gardu Induk terdekat, bila Gardu Induk terdekat dalam kapasitas tidak memungkinkan maka relay OCR perintah $\mathrm{CB}$ harus Off jadi tranformator aman. Dengan PMT off berarti ganguan sudah dilokalisir, dan kerugian yang diderita pada Industri terlalu tinggi bila Listrik dari PLN sampai off.

Alternatif untuk mengatasi permasalahan tersebut dibuat sistem yang bisa memantau kondisi Transformator setiap waktu. besaran daya listrik yang digunakan dengan ranges pembatasan yang bias memberi informasi bila beban lebih terjadi.

Pada penelitian sebelumnya sensor arus ACS712 pernah digunakan sebagai sensor arus pada sistem monitoring arus listrik jala-jala menggunakan power line carier oleh mahasiswa ITS (Mukhlas Arihutomo, Muhammad Rivai, suwito. 2012), tapi pada penelitian kali ini sensor arus ACS 712 digunakan untuk memonitoring arus pada sistem distribus listrik pada Industri dengan menggunakan mikrokontroler ATMega 16 sebagai control unit yang akan memproses data yang diterima dari sensor arus ACS712 dan sensor suhu LM35 menampilkannya pada layar LCD $2 \times 16$, dan di kirim melalui sms ke petugas Gardu Induk setempat.

\section{TINJAUAN PUSTAKA}

\section{Gardu Induk}

Gardu Induk (GI) adalah suatu instalasi yang terdiri dari relay daya, peralatan hubung bagi, transformator, reactor, peralatan ukur dan pengaman yang merupakan bagian dari suatu system tenaga listrik.[6]

\section{Switch yard (switchgear)}

Switch yard adalah bagian utama dari Gardu Induk Konvensional, karena disini peralatan penyaluran tenaga/daya listrik dibangun menjadi Instalasi Utama.[6]

\section{Transformator Tenaga}

Transformator tenaga adalah peralatan listrik yang berfungsi untuk menyalurkan daya/tenaga dari tegangan tinggi ke tegangan rendah atau sebaliknya. Prinsip kerja Transformator dapat dilihat pada gambar 1. Transformator menggunakan prinsip hukum induksi faraday dan hukum lorentz dalam menyalurkan daya, dimana arus bolak balik yang mengalir mengelilingi suatu inti besi maka inti besi itu akan berubah menjadi magnet. Dan apabila magnet tersebut dikelilingi oleh suatu belitan maka pada kedua ujung belitan tersebut akan terjadi beda potensial.[6]

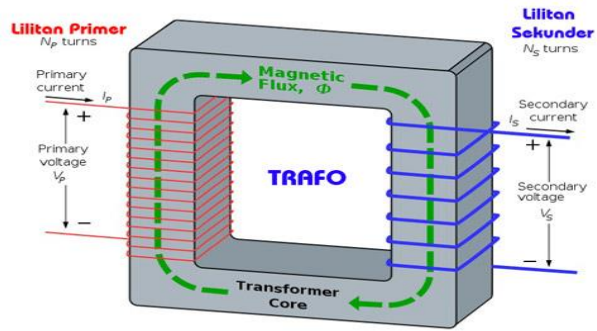

Gambar 1. Prinsip Kerja

\section{Sensor Arus ACS 712}

ACS712 adalah Hall Effect current sensor. Hall effect allegro ACS712 merupakan sensor yang presisi sebagai sensor arus AC atau DC dalam pembacaan arus di dalam dunia industri, otomotif, komersil dan sistem-sistem komunikasi.[1]

Pada umumnya aplikasi sensor ini biasanya digunakan untuk mengontrol motor, deteksi beban listrik, switchedmode power supplies dan proteksi beban 
berlebih, bentuk fisik dari sensor arus ACS712 dapat dilihat pada gambar 2

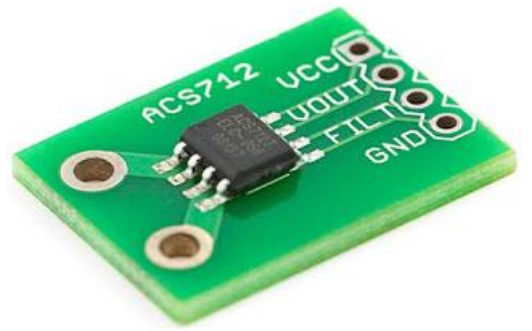

Gambar 2. Sensor arus ACS712

Sensor ini memiliki pembacaan dengan ketepatan yang tinggi, karena di dalamnya terdapat rangkaian low-offset linear Hall dengan satu lintasan yang terbuat dari tembaga. Cara kerja sensor ini adalah arus yang dibaca mengalir melalui kabel tembaga yang terdapat di dalamnya yang menghasilkan medan magnet yang ditangkap oleh integrated Hall IC dan diubah menjadi tegangan proporsional. Ketelitian dalam pembacaan sensor dioptimalkan dengan cara pemasangan komponen yang ada didalamnya antara penghantar yang menghasilkan medan magnet dengan hall transducer secara berdekatan.

\section{Sensor Suhu LM35}

LM35 adalah komponen sensor suhu berukuran kecil seperti transistor (TO-92), komponen yang sangat mudah digunakan ini mampu mengukur suhu hingga 100 derajad celcius. Sensor suhu LM35 adalah komponen elektronika yang memiliki fungsi untuk mengubah besaran suhu menjadi besaran listrik dalam bentuk tegangan. Sensor Suhu LM35 yang dipakai dalam penelitian ini berupa komponen elektronika elektronika yang diproduksi oleh National Semiconductor.[5]

LM35 memiliki keakuratan tinggi dan kemudahan perancangan jika dibandingkan dengan sensor suhu yang lain, LM35 juga mempunyai keluaran impedansi yang rendah dan linieritas yang tinggi sehingga dapat dengan mudah dihubungkan dengan rangkaian kendali khusus serta tidak memerlukan penyetelan lanjutan. Dengan tegangan keluaran yang terskala linear dengan suhu terukur, yakni 10 milivolt per 1 derajad celcius. Meskipun tegangan sensor ini dapat mencapai 30 volt akan tetapi yang diberikan ke sensor adalah sebesar 5 volt, sehingga dapat digunakan dengan catu daya tunggal dengan ketentuan bahwa LM35 hanya membutuhkan arus sebesar $60 \mu \mathrm{A}$ hal ini berarti LM35 mempunyai kemampuan menghasilkan panas (selfheating) dari sensor yang dapat menyebabkan kesalahan pembacaan yang rendah yaitu kurang dari $0,5^{\circ} \mathrm{C}$ pada suhu $25 \quad{ }^{\circ} \mathrm{C}$. Aplikasi-aplikasi seperti thermometer ruang digital, mesin pasteurisasi, atau termometer badan digital.[5]
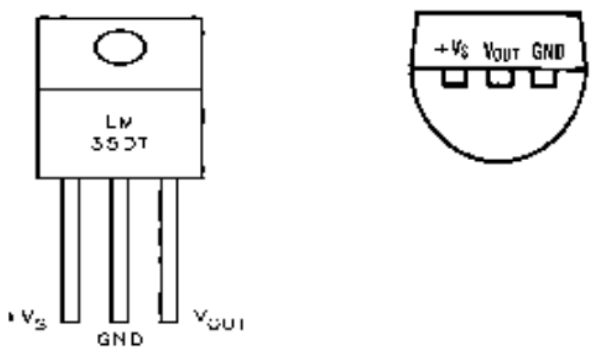

\section{Gambar 3. Sensor Suhu LM35}

Dari gambar 3 di atas dapat diketahui bahwa sensor suhu IC LM35 pada dasarnya memiliki 3 pin diantaranya yaitu, pin 1 berfungsi sebagai sumber tegangan kerja dari LM35, pin 2 atau tengah digunakan sebagai tegangan keluaran atau Vout dengan jangkauan kerja dari 0 Volt sampai dengan 1,5 Volt dengan tegangan operasi sensor LM35 yang dapat digunakan antar 4 Volt sampai 30 Volt. Keluaran sensor ini akan naik sebesar 10 $\mathrm{mV}$ setiap derajad celcius sehingga diperoleh persamaan sebagai berikut :

V LM35= Suhu*10 mV 


\section{Mikrokontroler ATMega 16}

Mikrokontroler ATMega 16 merupakan salah satu keluarga mikrokontroler AVR. Mikrokontroler AVR adalah mikrokontroler RISC (Reduce instructionset compute) 8 bit keluaran Atmel, yang merupakan salah satu mikrokontroler yang banyak digunakan saat ini.

AVR memiliki keunggulan dibanding mikrokontroler lain, keunggulan mikrokontroler AVR yaitu memiliki kecepatan eksekusi program yang lebih cepat karena sebagian besar instruksi dieksekusi dalam 1 siklus clock. Selain itu mikrokontroler AVR memiliki fitur yang lengkap (ADC internal, EEPROM internal, Timer/Counter, Watchdog Timer, PWM, Port I/O, Komunikasi serial, I2C, dll.

\section{Code Vision AVR}

Code Vision AVR adalah suatu alat bantu pemrograman (Programming tools) yang bekerja dalam lingkungan pengembangan perangkat lunak yang terintegrasi. CodeVision AVR merupakan software bahasa pemrograman bahasa $\mathrm{C}$ yang digunakan dalam menghasilkan program bahasa assembly untuk dimasukkan ke dalam mikrokontroler keluarga AVR dari ATMEL Corp.

Khusus untuk library fungsi, disamping library standar (seperti fungsifungsi matematik, manipulasi string, pengaksesan memori dan sebagainya), CodeVision $A V R$ juga menyediakan fungsi-fungsi tambahan yang sangat bermanfaat dalam pemrograman antarmuka AVR dengan perangkat luar yang umum digunakan dalam aplikasi kontrol. Beberapa fungsi library yang penting diantaranya adalah fungsi-fungsi untuk pengaksesan LCD, komunikasi I2C, IC RTC (Real time Clock), sensor suhu LM75, SPI (Serial Peripheral Interface) dan lain sebagainya.

\section{LCD (Liquid Cristal Display) $2 \times 16$ character}

LCD (Liquid Cristal Display) adalah suatu display dari bahan cairan kristal yang pengoprasiannya menggunakan sistem dot matriks. LCD banyak digunakan sebagai display dari alat-alat elektronika seperti kalkulator, multitester digital, Jam digital dan sebagainya. Bentuk LCD $2 \times 16$ dapat dilihat pada gambar 4 di bawah ini.

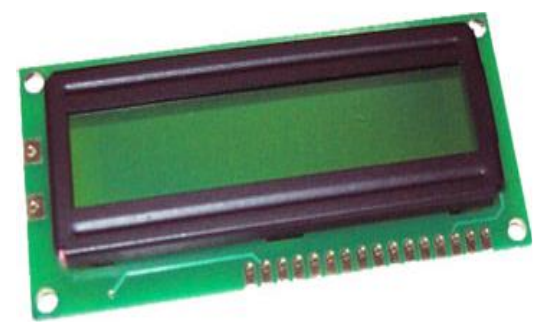

Gambar 4. Liquid Cristal Display (LCD) $2 \times 16$

\section{Modem Wavecom}

Kegunaan modem wavecom untuk sms gateaway dan server pulsa Wavecom adalah pabrikkan Perancis (berbasis di Issy-les-Moulineaux, Prancis), Wavecom SA berdiri sejak tahun 1993, dimulai sebagai konsultan teknik dan kantor sistem GSM jaringan nirkabel dan pada tahun 1996 mulai desain Wavecom Wireless GSM modul pertama dan didirikan pada tahun 1997, pertama berbasis GSM-GSM modul dan pengkodean khusus pada perintah. Sulit untuk menemukan referensi tipe navigasi modul sebagai pertama dibuat oleh Wavecom SA. Modem SMS dapat dilihat pada gambar 5 di bawah ini.

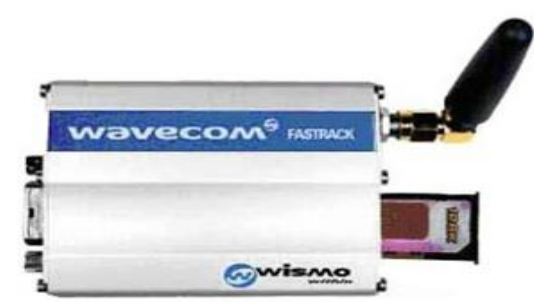

Gambar 5. Modem sms 


\section{METODE PENELITIAN}

\subsection{Studi literatur}

Mempelajari beban trafo150/20 KV yang dihasilkan dan serta, mempelajari cara kerja modem sms gateway, mikrokontroler AVR ATMega16 sebagai basis program, sensor Arus sebagai pembacaan Arus pada trafo,sensor Suhu sebagai pembacaan kondisi trafo, serta software yang digunakan dalam mendukung kinerja hardware. Sedangkan pengumpulan data yang dilakukan adalah pengumpulan data sms gateway, mikrokontroler AVR ATMega16, dan bahan-bahan lain yang diperlukan untuk pembuatan alat.

\subsection{Perancangan dan Pembuatan Alat}

Merancang suatu alat dengan menggunakan mikrokontroller ATMega16 dan membuat rangkaian hardware untuk monitoring trafo yang berbasis SMS. Blok diagram sistem yang dibuat dapat dilihat pada Gambar 6 di bawah ini.

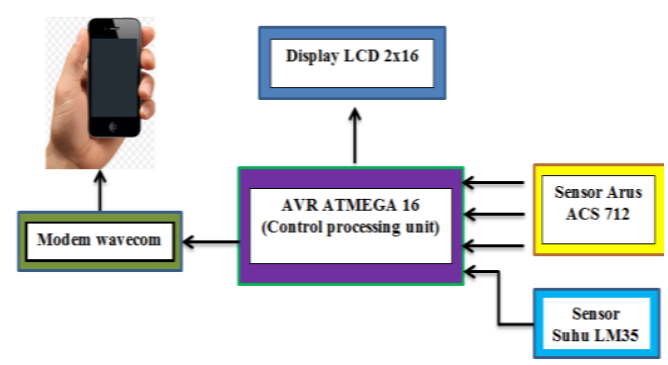

Gambar 6 Sistem monitoring tranformator berbasis mikrokontroler dan sms.

\subsection{Penelitian alat}

Alat yang telah dibuat, diuji apakah telah memenuhi hasil yang diharapkan atau belum. Apabila alat belum memenuhi harapan, maka dilakukan analisa dan perbaikan sehingga berhasil seperti yang diharapkan. Flowchart untuk metode penelitian dapat dilihat pada gambar 7 dibawah ini:

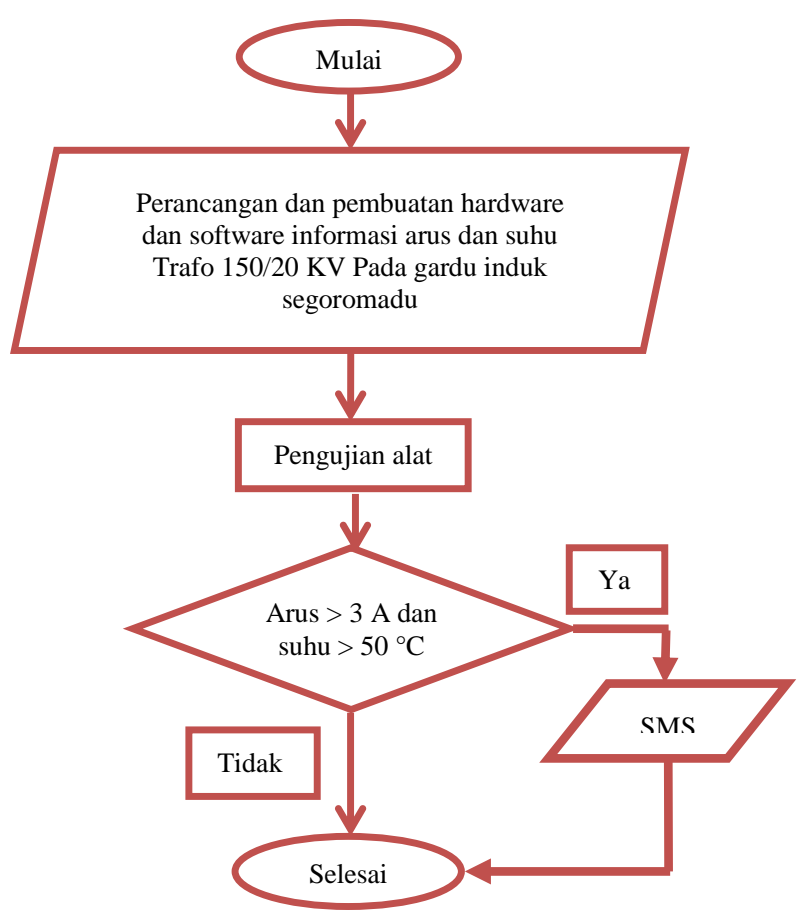

Gambar 7 Flowchart metode penelitian.

Flowchart Pengujian Sistem Secara Keseluruhan (Hardware dan Software) dapat dilihat pada gambar 8 di bawah ini.

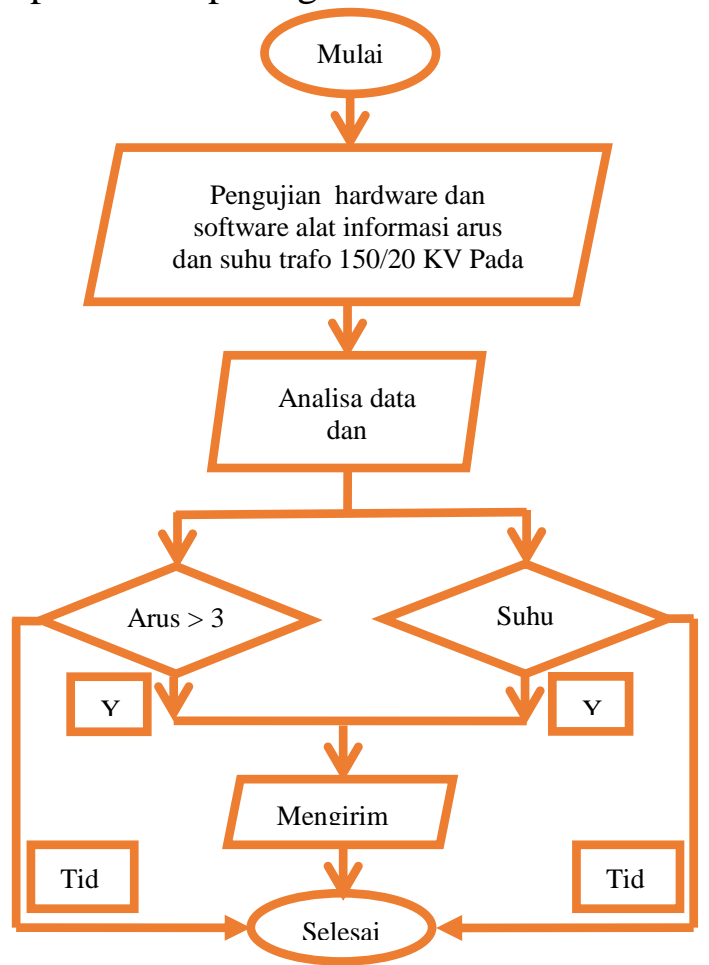

Gambar 8. Flowchart Pengujian Sistem Secara Keseluruhan (Hardware dan Software) 


\subsection{Analisa data}

Pada tahap ini akan dilakukan pengumpulan data dan analisa apakah sistem alat tersebut bekerja sesuai dengan yang diharapkan yaitu ketepatan dalam pembacaan sensor Arus, Suhu dan mengirim sms ke petugas yang berada di GI Segoromadu.

\section{PENGUJIAN DAN ANALISA ALAT}

Pada penelitian ini tidak dapat menguji alat di Gardu Induk Segoromadu. Hal ini disebabkan peralatan dalam keadaan online atau betegangan, sehingga sangat berbahaya untuk dilakukan pengujian, dan hanya bisa mencari informasi berupa data harian pada travo 150/20 KV. Pada pengujian ini dilakukan hanya untuk mensetting sensor arus atau kalibrasi sensor arus ACS712. Peralatan yang digunakan untuk mensetting sensor arus adalah peralatan listrik yang meliputi, Elemen Solder, Lampu Pijar, Pemanas Air, dan Setrika.

\subsection{Pengujian Software}

Pengujian pada software dilakukan pada subrutin program, apakah sudah bekerja sesuai dengan yang direncanakan. Pengujian yang dilakukan meliputi pengambilan data dari sensor ACS712 dan LM35.

\subsection{Pengujian Hardware}

Pengujian pada hardware dilakukan untuk mengetahui apakah hardware sudah bekerja sesuai dengan desain.

Pengujian yang dilakukan meliputi pengujian sensor arus ACS712 dan sensor suhu IC LM35, pengujian sistem minimum mikrokontroler ATMega16, LCD dan modem Wavecom.

\subsection{Pengujian Sistem Secara Keseluruhan (Hardware dan Software)}

Langkah pertama yang dilakukan adalah menggabungkan rangkaian sensor Arus ACS712, sensor suhu IC LM35 dan rangkaian LCD 2x16 pada mikrokontroler AVR ATMega16 yang berfungsi sebagai pengendali utama (central prosessing unit).

Rangkaian sensor arus ACS712 dan sensor suhu LM35 masuk pada port A (port $A D C$ ) mikrokontroler AVR ATMega16, sensor 1 masuk ke port A.0, sensor 2 masuk ke port A.2.

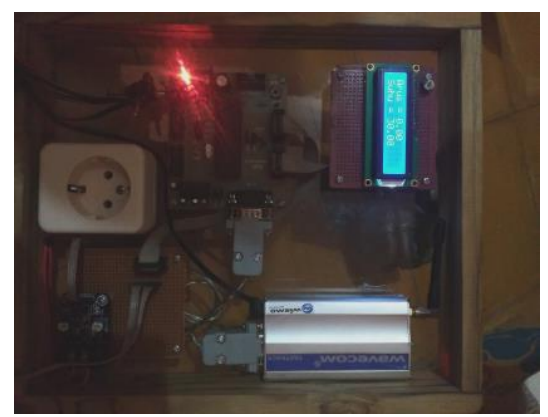

Gambar 9. Pengujian Sistem Secara Keseluruhan (Hardware dan Software)

Untuk unit display LCD 2x16 diaktifkan melalui port $\mathrm{C}$ dan catu daya 5 V. Pin 1 dan pin 2 pada LCD terhubung dengan VCC dan GND. Pin 3 LCD $2 \times 16$ berfungsi sebagai kontras sehingga pin ini diberi VR (variabel resistor) sebesar 10 $\mathrm{k} \Omega$ untuk mengatur kontras dengan cara memutar VR sampai didapat kontras yang baik. LCD memiliki tiga jalur kontrol dan jalur data yang berjumlah delapan atau empat bit.Tiga jalur kontrol, RS(pin 4), RW(pin5),E (pin 6) dihubungkan pada PC.0, PC.1, PC.2 mikrokontroler AVR ATMega16. Karena jalur data yang dipakai adalah 4 bit (DB4, DB5, DB6, DB7) terhubung pada PC.4, PC.5, PC.6, dan PC.7 mikrokontroler AVR ATMega16. Untuk menghidupkan backligt, pin 15 terhubung dengan diode

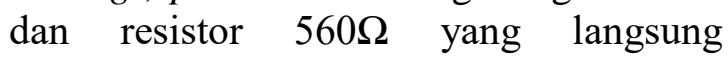
terhubung ke VCC dan pin 16 dihubungkan dengan GND. 
Setelah semua sudah terhubung dengan baik, program yang sudah dibuat dengan CodeVisionAVR didownload dengan menggunakan downloader AVR 910 USB programer yang terhubung pada port B, yaitu PB.5 (MOSI), PB.6 (MISO), PB7 (SCK) dan pin 9 (RESET). Karena downloader ini menggunakan AVR 910 USB programer, maka programer type pada CodeVisionAVR yang digunakan adalah Atmel AVRProg (AVR910). Setelah setting sudah sesuai kebutuhan, barulah program didownload ke mikrokontroler AVR ATMega16 dan system Monitoring Trafo 150/20 KV bisa dijalankan.

Dari hasil pengujian menunjukan alat dapat bekerja dan Sensor ACS712 pada alat dapat mengukur arus listrik yang melewati sensor arus diberi beban kurang dari 3 ampere arus CT (Curent Transformer) dan sensor suhu $<50^{\circ} \mathrm{C}$ maka alat tersebut belum memberi informasi berupa sms. Ketika arus >3 ampere arus CT (Curent Transformer) dan sensor suhu $>50^{\circ} \mathrm{C}$ maka alat monitoring dapat mengirim informasi berupa sms.

\subsection{Pengambilan Data dan Analisa}

Hasil percobaan pada sensor arus dan hasil pengukuran clamp Ampere Meter.

Nilai error hasil percobaan sensor arus dan pengukuran clamp Ampere Meter didapat dari data alat ukur yang dibandingkan dengan data hasil pengukuran sensor arus dengan menggunakan persamaan di bawah ini:

Nilai error $=\frac{\text { Nilai alat ukur }- \text { Nilai sensor arus }}{\text { Nilai sensor arus }} \times 100 \%$

Dari tabel di atas dapat dilihat tingkat akurasi dari sensor ACS712 dibandingkan dengan clamp Ampere meter.

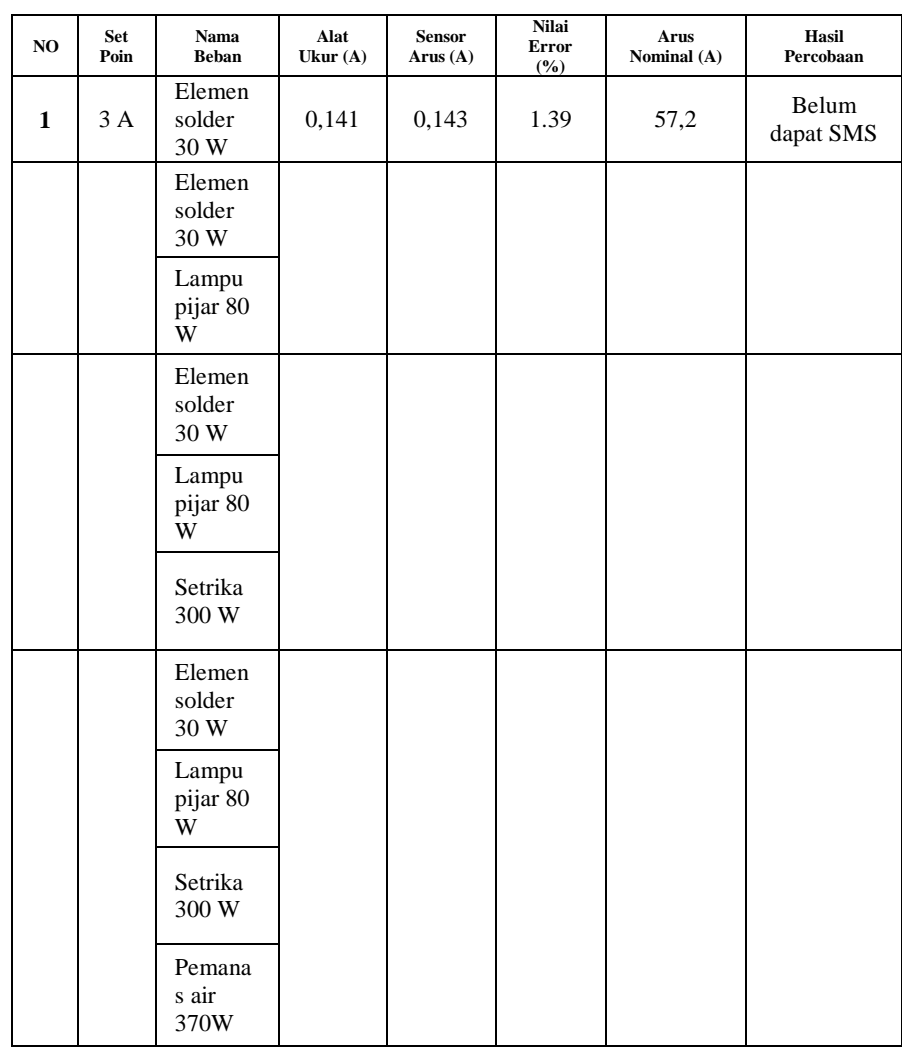

Nilai error maksimum pada sensor arus yaitu $1,39 \%$ dan data tersebut lebih rendah dari data sheet yaitu $1.5 \%$. Dan dapat disimpulkan bahwa semakin kecil arus yang diukur semakin rendah akurasi dari sensor ACS712.

Name Plate pada CT (Current Transformer) dapat dilihat pada gambar 10 di bawah ini.

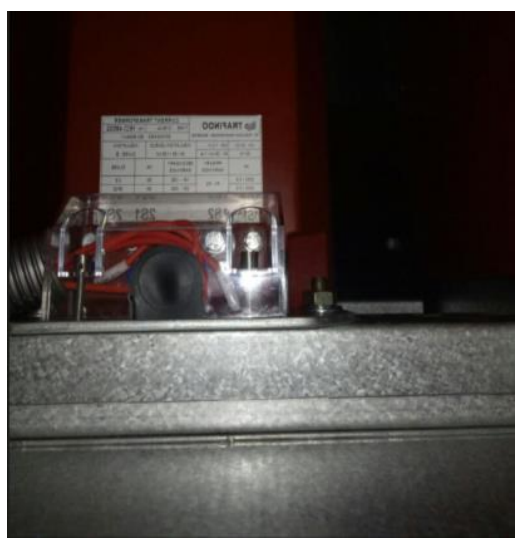

Gambar 10. Name Plate pada CT (Current Transformer) 
Pada gambar di atas batas arus CT (Current Transformer) yang digunakan 2000

\section{Ampere}

Cara perhitungan mencari arus CT (Current Transformer) sebagai berikut.

Arus CT (Curent Transformer) $=\frac{\text { arus max CT }}{5}=$ per 1 Ampere CT

$$
\frac{2000}{5} \text { Ampere }=400 \text { Ampere }
$$

1 Ampere arus CT $($ Curent Transformer $)=$ 400 Ampere arus nominal.

Pada perhitungan untuk mencari arus nominal pada CT (Curent Transformer) 3,52 Ampere, arus CT (Curent Transformer) sama dengan 1408 arus nominal pada travo $150 / 20 \mathrm{Kv} 60$ Mva.

\section{KESIMPULAN DAN SARAN}

\section{Kesimpulan}

1. Mikrokontroler AVR ATMega16 mampu berfungsi sebagai pengendali utama (central processing unit) yang mengendalikan proses dari system monitoring trafo 150/20 KV ini. Semua proses dapat dikendalikan dengan baik, mulai dari pembacaan nilai ADC (Analog to Digital Converter), perhitungan data arus atau suhu dapat ditampilkan pada LCD, dan memberikan informasi berupa SMS.

2. Tingkat akurasi dari sensor ACS712 dibandingkan dengan clamp Ampere meter memiliki nilai error maksimum pada sensor yaitu $1,39 \%$ dan data tersebut lebih rendah dari data sheet yaitu $1.5 \%$. Dapat disimpulkan bahwa semakin kecil arus yang diukur semakin rendah akurasi dari sensor ACS712.

3. Hasil perhitungan untuk mencari arus nominal pada CT (Curent Transformer) 3,52 Ampere, arus CT (Curent Transformer) sama dengan 1408 arus nominal pada travo 150/20 Kv $60 \mathrm{Mva}$.

\section{Saran}

1. Perlu diadakan penelitian kembali tentang perancangan alat monitoring transformator daya dengan interface yang berbeda.

2. Dengan merubah 2 variabel resistor yang ada pada Sensor ACS712 dengan variabel resistor type multi tone dapat mempermudah dalam mengkalibrasi alat dan hasilnya juga akan semakin akurat.

3. Perlu dilakukan perbandingan pengunaan sensor suhu LM35 dengan sensor suhu yang lebih baik agar pembacaan data suhu lebih akurat dan tepat.

4. Perlu diadakan penelitian kembali tentang tampilan di LCD dan SMS harus sesuai dengan informasi.

\section{DAFTAR PUSTAKA}

[1]. Andrianto, Heri. 2008. Pemrograman Mikrokontroler AVR ATMEGA 16 Menggunakan Bahasa $\mathrm{C}$ (Code Vision AVR). Informatika:Bandung.

[2]. Allegro Microsystem, inc. 2010. Data sheet ACS712.

[3]. Arihutomo, Mukhlas., Muhammad, Rivai., Suwito. Sistem Monitoring Arus Listrik jala-jala Menggunakan Power Line Carier, Jurnal Teknik ITS Vol. 1, No. 1 (Sept.2012) ISSN:23019271.

[4]. Bejo, Agus. 2008. C dan AVR Rahasia Kemudahan Bahasa C dalam Mikrokontroler ATMega 8535. GrahaI lmu:Yogyakarta.

[5].http://www.ti.com/Lm35/TexasInstru ments

[6]. PT. PLN (persero) P3BJB. Pedoman Pemeliharaan Trafo Tenaga. Pdf.

[7].http://www.wavecom.com.au/048prod uct/documents/648/User\%20Manual/f astrack/USERGUIDE3/Ver 0.pdf

[8].http://www.atmel.com/ATMega16 